\title{
Correction to: Structural analysis and proteomics studies on the Myoviridae vibriophage M4
}

\author{
Sayani Das ${ }^{1} \cdot$ Moumita Dutta $^{1} \cdot$ Anindito Sen ${ }^{1,2} \cdot$ Amar N. Ghosh $^{1}$
}

Published online: 21 June 2019

C) Springer-Verlag GmbH Austria, part of Springer Nature 2019

\section{Correction to: Archives of Virology (2019) 164:523-534 https://doi.org/10.1007/s00705-018-4100-7}

Unfortunately, the original article was published with an incorrect figure. Figure 11 contains errors and needs to be withdrawn. The following sentences shall be removed: The M4 tail is similar to that of T4, and therefore, the T4 tail tube protein model (PDB ID: 5NXF) was obtained from PDB and fitted into the tail tube of the reconstructed M4 tail map. The protein model and the map are shown in Fig. 11a and b, respectively, and the map containing the fitted protein model is shown in Fig. 11c.

The figure legend of Fig. 12 (a) should read as:

Crystal structure model of the T4 phage gp6 molecule.

Corrected references listed here:

11. Das S, Ghosh AN (2017) Preliminary characterization of El Tor Vibriophage M4. Intervirology 60:149-155. https ://doi.org/10.1159/000485835

21 Bebeacua C, Lai L, Vegge CS, Brøndsted L, van Heel M, Veesler D, Cambillau C (2013) Visualizing a complete siphoviridae member by single-particle electron microscopy: the structure of lactococcal phage TP901-1. J Virol 87:1061-1068

37. Bartual SG, Otero JM, Garcia-Doval C, Llamas-Saiz AL, Kahn R, Fox GC, van Raaij MJ (2010) Structure of the bacteriophage $\mathrm{T} 4$ long tail fiber receptor-binding tip. Proc Natl Acad Sci 107 (47):20287-20292. https://doi. org/10.1073/pnas.1011218107

38. Leiman PG, Shneider MM, Mesyanzhinov VV, Rossmann MG (2006) Evolution of bacteriophage tails: structure of T4 gene product 10. J Mol Biol 358(3):912-921

39. Artimo P, Arnold K, Baratin D et al (2012) ExPASy: SIB bioinformatics resource portal. Nucleic Acid Res 40(W1):W597-W603

Publisher's Note Springer Nature remains neutral with regard to jurisdictional claims in published maps and institutional affiliations.

The original article can be found online at https://doi.org/10.1007/ s00705-018-4100-7.

Amar N. Ghosh

ghosh.an@icmr.gov.in

Sayani Das

dsayani091@gmail.com

Moumita Dutta

mdutta16@gmail.com

Anindito Sen

andysen.mail@gmail.com

1 Division of Electron Microscopy, ICMR-National Institute of Cholera and Enteric Diseases, P-33 C.I.T Road, Scheme-XM, Beleghata, Kolkata 700010, India

2 Present Address: Microscopy and Imaging Center, Texas A \&M University, 301 Old Main Dr, College Station, TX 77843-2257, USA 